\title{
Isolation and identification of Viral Haemorrhagic Septicaemia (VHS) viruses from cod Gadus morhua with the ulcus syndrome and from haddock Melanogrammus aeglefinus having skin haemorrhages in the North Sea
}

\author{
D. A. Smail* \\ FRS Marine Laboratory, PO Box 101, Victoria Road, Aberdeen AB11 9DB, United Kingdom
}

\begin{abstract}
During fish disease surveys for marine rhabdoviruses in 1993 and 1995, the cod ulcus syndrome was seen widely in all ages of cod, especially the 2 to $5+$ year classes. Viral Haemorrhagic Septicaemia Virus (VHSV) was isolated from a small proportion of the lesion-positive fish and these isolates were identified by immunofluorescence or ELISA. A serendipitous observation of dermal petechiae on haddock was made. VHSV was isolated from this lesion for the first time indicating a new host species for VHSV.
\end{abstract}

KEY WORDS: Cod $\cdot$ Cod ulcus $\cdot$ Haddock $\cdot$ Dermal petechiae VHSV

Viral Haemorrhagic Septicaemia Virus (VHSV) is the most virulent virus for the freshwater trout farming industry in Europe (Wolf 1988). There is evidence that this novirhabdovirus has a widespread marine distribution and that the major virus genogroup from the EU countries comprises isolates from freshwater trout farms as well as many from wild marine species (Benmansour et al. 1997, Stone et al. 1997, Snow et al. 1999).

The ulcus syndrome in cod Gadus morhua L. is a raised minute papule on cod skin which progresses to bleeding and healing stages (Jensen \& Larsen 1979). A rhabdovirus isolation was made by Jensen et al. (1979), which was later identified as VHSV (Vestergard-Jørgensen \& Olesen 1987). Meyers et al.'s (1992) description of VHSV in Pacific cod Gadus macrocephalus from Alaska stimulated interest in carrying out a survey of skin ulcers in cod from the North Sea. Following a research cruise of the FRV 'Scotia' in 1993

•E-mail: smailda@marlab.ac.uk
(Cruise 1), Smail (1995) reported the isolation and identification of VHSV from cod in the North Sea with the ulcus syndrome. Mortensen et al. (1999) have also reported the isolation of VHSV from cod in the Baltic Sea.

This note describes another cod isolate from a single fish with ulcers from a 1995 North Sea fish disease research cruise (Cruise 2). In addition, the unusual observation of 2 haddock Melanogrammus aeglefinus with petechial haemorrhages of the tail was reported from Cruise 2 followed by the isolation of VHSV.

Materials and methods. Collection of samples: As part of a fish disease survey (McVicar et al. 1991) in coastal waters off eastern Scotland in 1993, cod were caught using BT101 fishing gear (48' Aberdeen trawl) with tickler chain and small mesh cod-end (Cruise1).

Following a track very similar to 1993 a follow-up fish disease survey was carried out in 1995 to further assess the status of the cod ulcus syndrome in North Sea cod (Cruise 2).

Fish recording and observations: For Cruise 1, all cod were washed, measured (total length) and the skin carefully inspected for the small papular lesions of cod ulcus syndrome described by Jensen \& Larsen (1979). The lesions were categorized from I to $\mathrm{V}$.

For Cruise 2, all cod were processed as above. A large number of herring were screened for skin haemorrhages and some sampled for virus isolation. Two haddock with skin haemorrhages were also sampled for virus isolation.

Virus isolation: For Cruise 1, ulcers were dissected from washed and alcohol-swabbed skin using a sterile scalpel. During the cruise each lesion was stored at $4^{\circ} \mathrm{C}$ in $9 \mathrm{ml}$ of Eagles Minimal Essential Medium (EMEM) 
with foetal calf serum $(10 \%)$ and high antibiotic concentrations (gentamycin $0.5 \mathrm{mg} \mathrm{ml}^{-1}$, kanamycin $50 \mu \mathrm{g}$ $\mathrm{ml}^{-1}$ and fungizone $12.5 \mathrm{\mu g} \mathrm{ml}^{-1}$ ). This is termed Transport Medium (TM). The samples were processed $8 \mathrm{~d}$ later.

Ulcers were sliced to fine pieces with scalpels and homogenised. Polyethylene glycol was added to the homogenate to $7 \%(\mathrm{w} / \mathrm{v})$ final dilution after the procedure of Batts \& Winton (1989). The supernatant was sterile filtered $(0.45 \mu \mathrm{m}$ pore size $)$ and 2 wells of EPC cells (Fijan et al. 1983) inoculated with undiluted and 1:10 diluted inoculum. Inoculum was adsorbed for $1 \mathrm{~h}$ at $15^{\circ} \mathrm{C}$, removed, and then EMEM with foetal calf serum $(10 \%)$ and $26 \mathrm{mM}$ Tris buffer (EMEM-t10) was replaced. Plates were incubated at $15^{\circ} \mathrm{C}$. After $10 \mathrm{~d}$, plates were examined microscopically for cytopathic effect and passage was then carried out to fresh epithelioma papilloma cyprini (EPC) cells.

For Cruise 2 samples the storage conditions differed and direct inoculation of the inoculum was used. Cod ulcers were dissected from affected skin using a scalpel; tissues were snap frozen in liquid nitrogen, stored for up to $14 \mathrm{~d}$ and thawed rapidly. Kidney and spleen were likewise stored from a few fish. Haemorrhaged skin and internal organs (kidney and spleen) from herring and haddock were frozen in liquid nitrogen at sea and thawed rapidly before virus testing. Incubation in 9 volumes of TM followed for up to $72 \mathrm{~h}$ at $4^{\circ} \mathrm{C}$ to decontaminate the tissues. Organ pools were homogenised in the original TM as above and skin ulcers were ground by mortar and pestle. Homogenates were clarified by centrifugation at $1250 \times g$ for $20 \mathrm{~min}$. EPC cells in 24-well plates were removed of EMEMt10, pretreated with $7 \%$ PEG in EMEM with $2 \%$ of foetal calf serum (EMEM-t2) for $10 \mathrm{~min}$; new EMEMt10 was added to each well and EPC cells were inoculated with 2 dilutions of the inoculum as above. Cultures were incubated at $15^{\circ} \mathrm{C}$ for $21 \mathrm{~d}$, read for cytopathic effect (CPE) and passaged to new EPC cells.

Supernatants from wells showing CPE were passed filtered $(0.45 \mu \mathrm{m}$ pore size) to fresh EPC cells. Where CPE reappeared in the inoculated wells, an aliquot of supernatant was stored at $-70^{\circ} \mathrm{C}$ for virus identification.
Virus identification by immunofluorescence (IF): The isolates H19/1/93 and H17/5/93 were identified by IF on EPC cells, using the method of Lorenzen et al. (1988). The monoclonal antibody IP5B11 to the VHSV $\mathrm{N}$ protein (given by N. Lorenzen) was used.

Virus ELISA: Virus identification was carried out by sandwich enzyme-linked immunosorbent assay using monoclonal (Mab) and polyclonal antibodies. Immunoassay plates were coated overnight with rabbit immunoglobulins to the $\mathrm{F} 1$ strain of VHSV (given by N Olesen) diluted $10^{-2}$ in sodium carbonate buffer $(0.05 \mathrm{M}$, $\mathrm{pH} 9.6)$ at $37^{\circ} \mathrm{C}$. Plates were washed in PBS-Tween 20 $(0.05 \% \mathrm{v} / \mathrm{v})$ (PBS-T) and then treated with $5 \%$ normal goat serum in coating buffer as blocker for $1 \mathrm{~h}$ at $37^{\circ} \mathrm{C}$, followed by washing. Tissue culture supernatants diluted 2 or $4 \times$ in coating buffer were added to the plates, incubated for $1 \mathrm{~h}$ at $37^{\circ} \mathrm{C}$ and then washed as above. Test wells were incubated for $1 \mathrm{~h}$ at $37^{\circ} \mathrm{C}$ with Mab to $\mathrm{N}$ protein (IP5B11), 1:50 dilution in coating buffer then washed. Incubation followed with goat anti-mouse IgG (whole molecule) peroxidase conjogate (Sigma) at $10^{-3}$ dilution in PBS-T. Plates were washed and liquid tetramethylbenzidine (TMB) was added for peroxidase colorimetric detection. Absorbances $(A)$ from virus culture supernatants were read at $450 \mathrm{~nm}$ against cell control supernatant. A test/control culture absorbance ratio was given as $A$ at $450 \mathrm{~nm}$ for test wells divided by $A$ for control wells.

Results and discussion. Twenty-three trawls were carried out by the FRV 'Scotia' from 5 to 9 June 1993 and $328 \mathrm{cod}$ were inspected for skin ulcers (Cruise 1). A total of $47 / 328(14.3 \%)$ cod showed the cod ulcus syndrome (Table 1). The haul stations ranged from off St Abbs Head, eastern Scotland, to 50 miles east of Shetland. Eleven stations were east of the Firth of Forth, 1 in the Moray Firth, 2 southeast of Fair Isle, 1 south of Shetland and 8 east of Shetland.

Seventeen trawls were carried out by the FRV 'Scotia III' from 10 to 14 June 1995 (Cruise 2). Nine stations were east of the Firth of Forth, 1 in the Moray Firth, 3 southeast of Fair Isle and 3 east of Shetland.

A total of 363 cod were examined for ulcers and 2330 herring Clupea harengus for dermal haemorrhages (Table 1). A total of $32 / 363(8.8 \%$ ) of cod exhibited

Table 1. Summary information on cod, haddock and herring examined for skin lesions, in 1993 and 1995, North Sea. NS = not sampled. +ve $=$ positive

\begin{tabular}{|ccccccc|}
\hline Cruise & Year & $\begin{array}{c}\text { Host } \\
\text { species }\end{array}$ & $\begin{array}{c}\text { No. of fish } \\
\text { examined }\end{array}$ & $\begin{array}{c}\text { No. with } \\
\text { lesion/type }\end{array}$ & $\begin{array}{c}\text { No. virus +ve/no. fish tested } \\
\text { Skin } \\
\text { Organs }\end{array}$ \\
\hline 1 & 1993 & Cod & 328 & $47 /$ ulcer & $2 / 19$ & NS \\
2 & 1995 & Cod & 363 & $32 /$ ulcer & $1 / 16$ & $0 / 16$ \\
2 & 1995 & Herring & 2330 & $47 /$ haemorrhage & $0 / 12$ & $0 / 26$ \\
2 & 1995 & Haddock & 2 & 2/haemorrhage & $2 / 2$ & $0 / 1$ \\
\hline
\end{tabular}




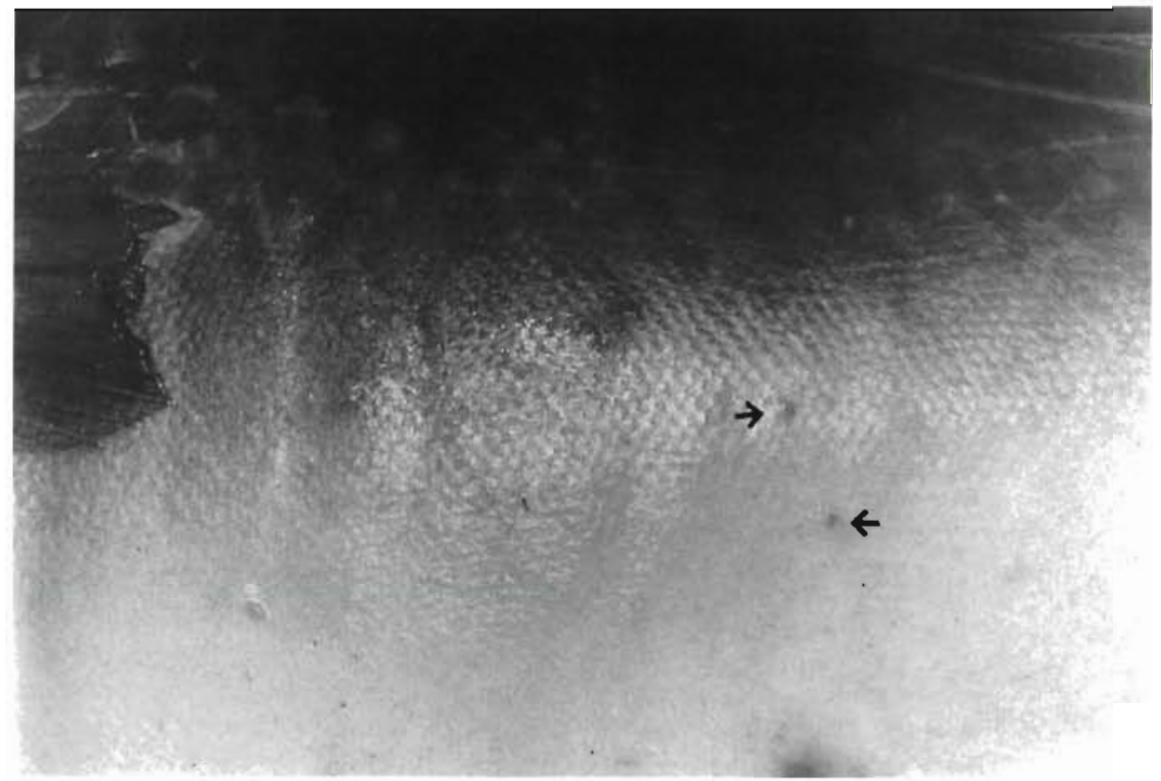

Fig. 1. Cod skin ulcers, June 1993 showing 2 minute raised papules at the centre of the photo (arrowed)

ulcers (Fig. 1) and 47/2330 (2.0\%) herring showed skin haemorrhages (Table 1). Only the early papular stages I and II of the cod ulcus lesion were seen. No internal lesions were observed on the liver, spleen or gut of any cod with external skin ulcers, which were more common on older fish of the 3 to $5+$ than the 1 to $2+$ year classes (Table 2). Year classes were derived from total length measurements taken in sampling, compared to year classes as determined by otolith measurements and length data from other hauls of cod in 1993 and 1995, from a similar area at the same time of year (A. Newton pers comm.).

Herring showed degrees of skin haemorrhaging, but such haemorrhages were dissimilar to the lesions

Table 2. Year classes of cod with ulcers, derived from cod length data, Cruise 1, 1993, and Cruise 2, 1995, for hauls only of cod with ulcers

\begin{tabular}{|lrrr|}
\hline Year class & Healthy cod & Cod ulcers & $\%$ ulcus \\
\hline Cruise 1, 1993 & & & \\
$1+$ & 118 & 3 & 2.5 \\
$2+$ & 137 & 11 & 7.4 \\
$3+$ & 24 & 21 & 46.7 \\
$4+$ & 3 & 7 & 70.0 \\
$5+$ & 0 & 5 & 100.0 \\
Totals & 282 & 47 & \\
Cruise 2, 1995 & & & \\
$1+$ & 93 & 5 & 5.1 \\
$2+$ & 206 & 12 & 5.5 \\
$3+$ & 20 & 8 & 28.5 \\
$4+$ & 1 & 5 & 83.3 \\
$5+$ & 0 & 2 & 100.0 \\
Totals & 320 & 32 & \\
\hline
\end{tabular}

described by Meyers et al. (1994) in Pacific herring, since the haemorrhages were superficial and not associated with an ulcer or scale loss.

The 2 haddock showed deep petechial haemorrhaging on the tail (Fig. 2) a condition previously described at this laboratory as haddock 'rough tail' (J. Gauld pers. comm.).

In Cruise 1, 2/19 fish samples showed CPE by Day 10 post-inoculation in wells with undiluted inoculum only. After slow initial growth the isolates multiplied quickly. Isolates were designated H17/5/93 and H19/1/93 for haul number, fish number and year. Each isolate was identified as VHSV by IF. Control slides remained unstained.

In Cruise 2, only 1 isolation (H16/7/95) was made from the cod ulcer homogenates (Table 1). No virus was isolated from the organ pool of this same fish. H16/7/95 was confirmed as VHSV by ELISA with a positive/negative ratio of 4.3 for a $4 \times$ dilution of the test culture supernatant versus a cell control.

All of the samples from herring were negative for VHSV including skin lesions and organ pools of kidney and spleen. The skin ulcers from 2 haddock produced EPC CPE by Days 8 to 10 post-infection in the primary dilution well only. On passage, fast CPE was reproduced in $2 \mathrm{~d}$ for both isolates. By contrast, CPE was not produced from the spleen and kidney pool from 1 haddock. Isolates were stored at $-70^{\circ} \mathrm{C}$ for reference. The virus isolates from haddock were identified as VHSV by IF showing strongly fluorescing foci.

The 2 cod isolates from 1993 and 1 from 1995 were serogrouped by N. J. Olesen according to methods and reagents described by Olesen et al. (1993). Isolates 


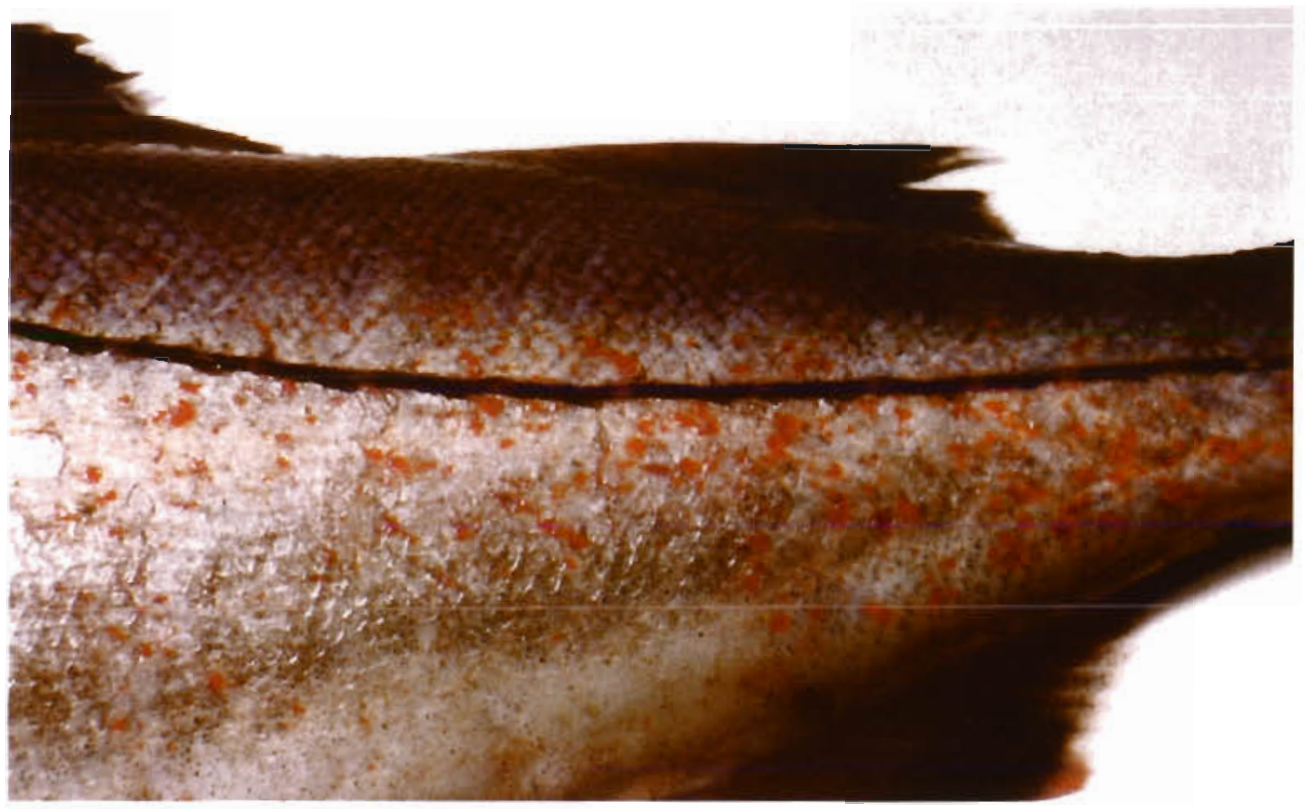

Fig. 2. Haddock tail showing minute petechiae within the dermis, June 1995, east of Shetland
H17/5/93 and H19/1/93 were determined as European Serogroup II. Isolate H16/7/95 was Serogroup III, within the European group. The haddock isolates H17/1/95 and H17/2/95 were identified as Serogroup II. The Serogroups I-III should be regarded only as sub-types of a single Serotype I, comprising most of the known isolates of VHSV.

The isolation of VHSV from a cod ulcus skin sample on Cruise 2 adds to previously reported evidence that cod is a marine host of VHSV in the North and Baltic Seas (Smail 1995, Mortensen et al. 1999).

The isolates from cod and haddock were identified as VHSV and represent de novo isolations from marine hosts. The prediction of Wolf (1988) that 'perhaps cod and related gadoids elsewhere will (with respect to cod ulcus syndrome) eventually be shown to have the condition' has been borne out in time. These isolations from cod support the first isolation of a rhabdovirus from cod ulcus lesions by Jensen et al. (1979) that was later identified by Vestergard-Jørgensen \& Olesen (1987) as true VHSV (M Rhabdo 79). In addition this original cod isolate has been demonstrated to be genetically related to other cod isolates derived from the Baltic Sea in 1996 (Snow et al. 1999).

The isolation rate was low from the cod skin samples tested. Possible explanations for this finding are: (1) there are very low levels of virus in cod ulcers because VHS is a systemic infection in cod with ulcers and there is no virus correlation with ulcers (Mortensen et al. 1999); (2) virus was inactivated in storage until the cell culture was carried out, i.e. in Cruise 1 , storage was at $4^{\circ} \mathrm{C}$ and not in liquid nitrogen; (3) the cod ulcer isolate of VHSV does not replicate optimally in EPC cells BF-2 cells being superior (Lorenzen et al. 1999); (4) virus extraction was sub-optimal.

The isolation of VHSV from cod ulcus lesions raises the question of whether the lesions are actually caused by VHSV or whether VHSV is a concomitant infection. Jensen \& Larsen (1982) attempted to answer this question but were unable to prove Rivers' postulates for either the rhabdovirus or iridovirus they isolated. A major limiting factor of the experiment was the possible previous exposure of the wild caught cod to either virus, with the development of a pre-existing immunity. A cod pathogenicity experiment to determine the virulence of the $1995 \mathrm{cod}$ isolate (H16/7/95) to codling (Snow et al. 2000 - in this issue) showed that this strain was pathogenic by injection with $80 \%$ mortality but not by waterborne infection. VHSV was recovered and re-identified from the lesion of a single fish and from the fin of another supporting the epitheliotropic nature of the virus (Estepa et al. 1993).

The first isolation of VHSV from petechiae on the skin of haddock indicates this gadoid as a new host species for VHS. With respect to the genotype classification, isolates H17/1/95 and H17/2/95 were classified by Snow et al. (1999) within a single genotype. This comprised the Scottish Gigha turbot isolate 860/94, the Scottish cod isolates H17/5/93, H19/1/93 and H16/7/95, North Sea isolates 4p51 (argentine), 4p59 (cod) and a Skagerrak isolate 4p168 (herring) of Mortensen et al. (1999), the Irish turbot isolate, F 13.02.97 (McArdle unpubl.) and a Norway pout isolate 2p51 from the Skagerrak (Mortensen et al. 1999). The classification by Snow et al. (1999) of the isolates around the British Isles into a single genotype supports 
the work of Benmansour et al. (1997) and Stone et al. (1997). Recent isolations by Mortensen et al. (1999) extend the geographic range of this very homogeneous pool of isolates from the North Sea into the Skagerrak close to Scandinavia.

This note confirms a previous report of 2 cod isolates, reports a third isolation and establishes haddock as a newly documented marine host for VHSV. Investigation of the virulence of these isolates for juvenile cod is of great importance in relation to the growth of the cod farming industry in the UK, Norway and Iceland.

Acknowledgements. I thank Dr David Bruno for the photography of fish at sea. I acknowledge the sub-typing of virus strains by Dr Niels Jørgen Olesen at the EU Reference Laboratory, Aarhus. I thank Dr Ken MacKenzie and Nicola Bain for assistance with sea fish sampling. I thank Dr Mike Snow, Dr Julie King and Dr Rob Raynard for reading the manuscript.

\section{LITERATURE CITED}

Batts WN, Winton JR (1989) Enhanced detection of infectious haematopoietic necrosis virus and other fish viruses by pretreatment of cell monolayers with polyethylene glycol. J Aquat Anim Health 1:284-290

Benmansour A, Basurco B, Monnier AF, Vende P, Winton JR, deKinkelin $P$ (1997) Sequence variation of the glycoprotein gene identifies three distinct lineages within field isolates of viral haemorrhagic septicaemia virus, a fish rhabdovirus. J Gen Virol 78:2837-2846

Estepa A, Frias D, Coll JM (1993) In vitro susceptibility of rainbow trout fin cells to viral haemorrhagic septicaemia virus. Dis Aquat Org 15:35-39

Fijan N, Sulimanovic D, Bearzotti M, Muzinic D, Zwillenberg LO, Chilmonczyk S, Vautherot JF, de Kinkelin P (1983) Some properties of the epithelioma papulosum cyprini (EPC) cell line from carp (Cyprinus carpio). Ann Virol (Paris) 134E:207-220

Jensen NJ, Larsen JL (1979) The ulcus-syndrome in cod (Gadus morhua) I. A pathological and histopathological study. Nord Veterinaermed 31:222-228

Jensen NJ, Larsen JL (1982) The ulcus-syndrome in cod (Gadus morhua) IV Transmission experiments with two viruses isolated from cod and Vibrio anguillarum. Nord Veterinaermed 34:136-142

Jensen NJ, Bloch B, Larsen JL (1979) The ulcus-syndrome in cod (Gadus morhua) III. A preliminary virological report. Nord Vetmed 31:436-442

Editorial responsibility: Jo-Ann Leong,

Corvallis, Oregon, USA
Lorenzen N, Olesen NJ, Vestergard-Jørgensen PE (1988) Production and characterisation of monoclonal antibodies to four egtved virus structural proteins. Dis Aquat Org 4 . $35-42$

Lorenzen E, Carstensen B, Olesen NJ (1999) Inter-laboratory comparison of cell lines for susceptibility to three viruses: VHSV, IHNV and IPNV. Dis Aquat Org 37:81-88

McVicar AH, Bruno DW, Fraser CO (1991) Fish disease in the North Sea in relation to sewage sludge dumping. Mar Pollut Bull 19:169-173

Meyers TR, Sullivan J, Emmenegger E, Follett J, Short S, Batts WN, Winton JR (1992) Identification of viral haemorrhagic septicaemia virus isolated from Pacific cod (Gadus macrocephalus) in Prince William Sound, Alaska, USA. Dis Aquat Org 12:167-175

Meyers TR, Short S, Lipson K, Batts WN, Winton JR, Wilcock J, Brown E (1994) Association of viral haemorrhagic septicaemia virus with epizootic haemorrhages of the skin in Pacific herring Clupea harengus pallasi from Prince William Sound and Kodiak Island, Alaska, USA. Dis Aquat Org 19:27-37

Mortensen HF, Heur OE, Lorenzen N, Otte L, Olesen NJ (1999) Isolation of viral haemorrhagic septicaemia virus from wild marine species in the Baltic Sea, Kattegat, Skagerrak and the North Sea. Virus Res 63:97-108

Olesen NJ, Lorenzen N, Jørgensen PEV (1993) Serological differences among isolates of viral haemorrhagic septicaemia virus detected by neutralising monoclonal and polyclonal antibodies. Dis Aquat Org 16:163-170

Smail DA (1995) Isolation and identification of viral haemorrhagic septicaemia (VHS) virus from North Sea cod (Gadus morhua L.). ICES CM 1995/F:15 Mariculture Committee

Snow M, Cunningham CO, Melvin WT, Kurath G (1999) Analysis of the nucleoprotein gene identifies distinct lineages of viral haemorrhagic septicaemia virus within the European marine environment. Virus Res 63:35-44

Snow M, Cunningham CO, Bricknell IR (2000) Susceptibility of juvenile Atlantic cod Gadus morhua to viral haemorrhagic septicaemia virus isolated from wild-caught cod. Dis Aquat Org 41:225-229

Stone DM, Way K, Dixon PF (1997) Nucleotide sequence of the glycoprotein gene of viral haemorrhagic septicaemia (VHS) viruses from different geographical areas: a link between VHS in farmed fish species and viruses isolated from North Sea cod (Gadus morhua L). J Gen Virol 78 . 1319-1326

Vestergard-Jørgensen PEV, Olesen NJ (1987) Cod ulcus syndrome rhabdovirus is indistinguishable from the Egtved (VHS) virus. Bull Eur Assoc Fish Pathol 7(3):73-74

Wolf K (1988) Fish viruses and fish viral diseases, Chap 24 Atlantic cod ulcus syndrome. Cornell University Press, Ithaca

Submitted: November 22, 1996; Accepted: April 18, 2000 Proofs received from author(s): June 30, 2000 